\title{
Formation of a draft model of a national technology initiative specialist
}

\author{
Dina Merzlyakova ${ }^{1, *}$, Alexey Miroshnichenko ${ }^{2}$, Alexander Baranov $^{1}$, Valery Morozov $^{1}$, and \\ Artem Popkov ${ }^{1}$ \\ ${ }^{1}$ Udmurt State University, Universitetskaya Str., 1, 426034 Izhevsk, Russia \\ ${ }^{2}$ Glazov State Pedagogical Institute named after V.G. Korolenko, Pervomaiskaya Str., 25, 427621 \\ Glazov, Russia
}

\begin{abstract}
The article indicates the draft model of an NTI specialist, built on the basis of the generalized opinion of experts. Education as an integrated process is focused on the intellectual, spiritual and moral, creative, physical and/or professional development of a person. Based on the analysis of personality theories, the main criteria of the personality model of an NTI specialist are determined. An algorithm for group expert assessment of the personality model of an NTI specialist is presented. Methods for registering indicators of the formation of personality substructures of NTI specialists are pedagogical and psychological diagnostics and expert assessment. The tendencies of positive changes in the personality development of NTI specialists are revealed.
\end{abstract}

\section{Introduction}

In the first decade of the XXI century, the growth of the Russian economy was due to the country's expanding participation in world raw materials and energy markets. The subsequent series of economic crises determined the need to abandon dependence on raw materials and strengthen Russia's role in the high-tech markets.

The national technological initiative (NTI) is today one of the key landmarks for the development of our state. This is a state program of measures to create competitive products and services, which should make Russia a leader in the high-tech markets [1]. NTI is a national-level global challenge. Its implementation is the key to the success of our state in the era of high technologies. At the heart of a possible future breakthrough lies the transition to new technologies that shape the face of the economy. These are nano-, bio-, information technologies and digitalization as their symbiosis. Information technologies, artificial intelligence, new materials, genetic engineering and their integration prevail in the sixth technological paradigm. New industries also imply new professions. The existing changes allow us to believe that traditional professions are being transformed and education alone is no longer enough for life. For example, according to the atlas of new professions 3.0, developed by the Agency for Strategic Initiatives and Skolkovo Moscow School of Management, new sectors of employment will appear. They include:

1. Creative industries.

\footnotetext{
*Corresponding author: dinamerzlyakova26@gmail.com
} 
2. Economy of eco-recovery.

3. Virtual economy.

4. Human-centered services.

5. New technology sectors $[1,2]$.

The implementation of these professions will require a new generation of specialists with systemic interdisciplinary competencies, capable of solving new problems with new methods and means. The training of such specialists should begin at the level of general education and continue, corresponding to LLL (long-life learning). According to LLL, learning is a process of transforming life and professional experience with an emphasis on self-education. The teacher is only the organizer of the educational process, in which the modular principle of building educational programs dominates, and which widely presents educational technologies, interactive forms of teaching, project methods, etc. [3, 4].

The role of targeted training of specialists in the education system (general, professional, additional) for the industries of the future is increasing. There is a contradiction between this need and the insufficient development of the methodology for determining and forming the goal that the education system should be guided by - the model of an NTI specialist. This goal requires its qualimetrical justification and diagnostic setting. These conditions are the basis of the technological approach in the design of educational programs at all levels (V.P. Bespalko and M.V. Klarin) [5]) [2].

\section{Materials and Methods}

In the process of writing the article, we revised scientific literature. Methods used were analysis, synthesis, structuring, and group expert assessment.

\section{Results and Discussion}

We proceed from the assumption that the formation of a model of an NTI specialist is a continuous process, covering the level of general, professional, and further education, focused on the goal set by the NTI industry(ies). The presented results are an integral part of the study on the formation of qualimetrically grounded models of an NTI graduate, NTI teacher, and NTI specialist. The objective of the study is to qualimetrically substantiate the content and stages of the formation of a model of an NTI specialist. Within the framework of this article, the results of work on the formation of a draft model of an NTI specialist are presented.

As the process of forming a model of an NTI specialist is continuous and covers the branches of education and areas of NTI activity, it is necessary to:

- consider the participants in the formation of the model of an NTI specialist as experts capable of providing information under uncertainty;

- include teachers of all levels of the education system in the composition of experts, who explicitly (implicitly) interact in the formation of an NTI specialist, specialists in NTI industries (both existing and goal-oriented NTI industries);

- examine the draft model of an NTI specialist according to the algorithm of the method of group expert assessments (GEA), which will provide a qualimetric justification of the developed model.

The key stage of the expertise is the development of the object of the expertise - the draft model of the NTI specialist. The first stage of its development was the formation of a working group (WG), which was entrusted with administrative, organizational, methodological, and technical functions. The areas of responsibility of each member of the working group, key control points and targets for the results of the examination were identified. 
At the second stage, the WG identified a pool of candidates for experts. It included 138 potential experts. They were 54 teachers of general education organizations, 44 teachers of universities and colleges, and 40 specialists of the NTI industries.

At the third stage, the WG formed a pool of potential experts, including 98 people. They were 34 teachers of general education organizations, 37 teachers of universities and colleges, and 27 specialists of the NTI industries.

At the fourth stage, the WG conducted an analysis of the models to select the basis for building a model project for an NTI specialist. In total, 13 models were analyzed competence, functional, personal $[6,7]$. A fragment of the analysis results is presented in Table 1.

Table 1. Comparative characteristics of personality models

\begin{tabular}{|c|c|c|c|}
\hline Model & Approach & Author & Number of criteria \\
\hline $16 \mathrm{PF}$ & Lexicographic & R. Cattel & 16 \\
\hline EPI & Dispositional & H. Eysenck & 3 \\
\hline $\begin{array}{c}\text { BigFive (NEO-PI-R \& } \\
\text { BFI }\end{array}$ & $\begin{array}{l}\text { Lexicographic and } \\
\text { dispositional }\end{array}$ & Goldberg & 5 \\
\hline MBTI (Keirsey, DISC) & Typological & Myers-Briggs & 4 \\
\hline MMPI & \multirow{2}{*}{ Clinical } & Hathaway-McCanley & 10 \\
\hline CPI & & Gough & 20 \\
\hline OPQ & \multirow[t]{3}{*}{ Professional } & Saville-Holdsworth & 32 \\
\hline Wave & & Saville & 36 \\
\hline HPI & & Hogan & 7 \\
\hline $\begin{array}{c}\text { Dynamic personality } \\
\text { structure }\end{array}$ & Structural & K.K. Platonov & 4 \\
\hline Activity & Subjective & $\begin{array}{c}\text { S.L. Rubinstein, K.A. } \\
\text { Abulkhanova- } \\
\text { Slavskaia }\end{array}$ & 7 \\
\hline Personality development & Socialization & $\begin{array}{l}\text { R.S. Nemov, V.A. } \\
\text { Mudrik, A.G. } \\
\text { Asmolov }\end{array}$ & 14 \\
\hline $\begin{array}{l}\text { A competence model of a } \\
\text { university graduate }\end{array}$ & $\begin{array}{l}\text { General cultural } \\
\text { Professional }\end{array}$ & FSES HE & $24-30$ \\
\hline
\end{tabular}

The examples of approaches to the structuring and organization of personal characteristics and the models implemented within the framework of the considered approaches clearly show the diversity that any practical task that requires measuring and diagnosing personality faces. Thus, the concept of personality is a fairly integral construct that includes both biological qualities, individual personality traits, and social ones. Based on the results of the analysis of personality models, the WG decided to use the personality model of K.K. Platonov as a basis for building a model of an NTI specialist (Table 2) [8]. In our opinion, this personality structure not only determines the personality structure, but builds a system for the development and formation of the necessary personality traits.

Table 2. Dynamic personality structure (acc. to K.P. Platonov)

\begin{tabular}{|c|c|c|c|}
\hline $\begin{array}{c}\text { Personality } \\
\text { subsystem }\end{array}$ & Subsystem structure & Biological to social ratio & $\begin{array}{c}\text { Forms of development } \\
\text { and formation }\end{array}$ \\
\hline $\begin{array}{c}\text { Personality } \\
\text { orientation }\end{array}$ & $\begin{array}{c}\text { Worldview, drives, desires, } \\
\text { aspirations, inclinations, } \\
\text { ideals, and beliefs }\end{array}$ & Social conditioning & Upbringing \\
\hline Social experience & $\begin{array}{c}\text { knowledge, skills, abilities } \\
\text { and habits }\end{array}$ & Socio-biological base & Education \\
\hline $\begin{array}{c}\text { Individual } \\
\text { psychological } \\
\text { features }\end{array}$ & $\begin{array}{c}\text { Features of cognitive } \\
\text { processes (memory, thinking, } \\
\text { will, feelings, etc.) }\end{array}$ & Biosocial conditioning & Exercises \\
\hline $\begin{array}{c}\text { Biopsychic } \\
\text { properties }\end{array}$ & $\begin{array}{c}\text { Speed, intensity of mental } \\
\text { processes, gender, age }\end{array}$ & Biological conditioning & Training \\
\hline
\end{tabular}


The object of examination is the draft model of an NTI specialist represented in Table 3, which includes the following sections. Section 1 and 2 are substructures and their content, corresponding to the personality model of K.K. Platonov. Section 3 lists the qualities that an NTI specialist should possess. For example, experts have identified such qualities of an NTI specialist as responsibility, persistence, initiative. Section 4 presents the means of forming and diagnosing the qualities of a model of an NTI specialist. This section allows concretizing the methodological and diagnostic resources necessary for the formation of an NTI specialist. For example, the method of observation in the process of activity, expert assessment, psychological tests were named as diagnostic methods. Section 5 presents the levels of formation of the quality of the specialist model: GE - general education, VE vocational education, FE - further education, PA - professional activity. This section is necessary to establish the continuity of the levels at which an NTI specialist is formed. A fragment of the draft model of an NTI specialist is presented in Table 3.

Table 3. A fragment of the draft model of an NTI specialist based on expert assessment [8]

\begin{tabular}{|c|c|c|c|c|}
\hline $\begin{array}{c}\text { Personality } \\
\text { subsystem 1. }\end{array}$ & $\begin{array}{c}\text { Subsystem content } \\
2 .\end{array}$ & $\begin{array}{c}\text { Specific features of } \\
\text { the image of an } \\
\text { NTI specialist 3. }\end{array}$ & $\begin{array}{c}\text { Means of forming and } \\
\text { diagnosing the } \\
\text { features of the image } \\
\text { of an NTI specialist 4. }\end{array}$ & $\begin{array}{c}\text { Levels of } \\
\text { formation of } \\
\text { personality } \\
\text { features } 5 .\end{array}$ \\
\hline $\begin{array}{c}\text { Personality } \\
\text { orientation }\end{array}$ & $\begin{array}{c}\text { Worldview, drives, } \\
\text { desires, aspirations, } \\
\text { inclinations, ideals, } \\
\text { and beliefs }\end{array}$ & $\begin{array}{c}\text { Responsibility, } \\
\text { motivation to } \\
\text { work, } \\
\text { perseverance, } \\
\text { proactivity. }\end{array}$ & $\begin{array}{c}\text { Observation in the } \\
\text { process of activity, } \\
\text { expert assessment, } \\
\text { psychological testing. }\end{array}$ & $\begin{array}{c}\mathrm{GE}-\mathrm{VE}-\mathrm{FE} \\
-\mathrm{PA}\end{array}$ \\
\hline
\end{tabular}

At the fifth stage, three expert groups were formed and the number of teachers of general educational organizations, university teachers, specialists in the NTI industries in an amount of 12 to 15 people. The experts were assigned the task of completing sections 3 and 4, focusing on personal experience and understanding of the features of the model of an NTI specialist. A fragment of the results of filling the table is presented in Table 4.

Table 4. A fragment of the draft model of an NTI specialist and means of forming and diagnosing the features based on expert assessment

\begin{tabular}{|c|c|c|c|}
\hline $\begin{array}{c}\text { Personality } \\
\text { subsystem } 1 .\end{array}$ & $\begin{array}{c}\text { Subsystem content } \\
2 .\end{array}$ & $\begin{array}{c}\text { Specific features of the } \\
\text { model of an NTI specialist } \\
3 .\end{array}$ & $\begin{array}{l}\text { Means of forming and diagnosing the } \\
\text { features of the model of an NTI } \\
\text { specialist } 4 .\end{array}$ \\
\hline Orientation & $\begin{array}{l}\text { Interests, ideals, } \\
\text { motives, desires, } \\
\text { hierarchy of values. }\end{array}$ & $\begin{array}{c}\text { Personality orientation. } \\
\text { Internal control locus, } \\
\text { responsibility. } \\
\text { High need for achievement. } \\
\text { High level of profession } \\
\text { value. } \\
\text { Low level of egocentrism. }\end{array}$ & $\begin{array}{l}\text { Techniques. } \\
\text { 1. Determination of personality } \\
\text { orientation. } \\
\text { 2. The assessment scale for the need } \\
\text { for achievement. } \\
\text { Scale of conscientiousness (V.V. } \\
\text { Melnikov, L.T. Iampolskii) [9]. } \\
\text { Upbringing methods: } \\
\text { 1. Explanatory - reproductive. } \\
\text { 2. Problem-situational. } \\
\text { 3. Methods of training and exercise, } \\
\text { stimulation, inhibition, guidance, self- } \\
\text { education [10-11]. }\end{array}$ \\
\hline
\end{tabular}

At the sixth stage, the WG processed the results of the examination and presented to the experts a generalized version of the draft model of an NTI specialist. The experts had to rank the features of the model and the means of forming and diagnosing the qualities of the model of an NTI specialist on a 3point scale (3 - exactly corresponds, 2 - does not fully correspond, 1 - rather does not correspond, 0 does not correspond). Based on the ranking results, the WG excluded from the project the model of an NTI specialist of quality and means having an average rank of 1 and 0 . The numerical results on the number of qualities of the model of an NTI specialist and means of formation and diagnostics are presented in Table 5. 
Table 5. Numerical results by the number of features of the model of an NTI specialist and means of formation and diagnostics

\begin{tabular}{|c|c|c|c|}
\hline Personality subsystem & Subsystem structure & $\begin{array}{c}\text { Specific features } \\
\text { of the model of an } \\
\text { NTI specialist }\end{array}$ & $\begin{array}{c}\text { Means of forming } \\
\text { and diagnosing the } \\
\text { features of the } \\
\text { model of an NTI } \\
\text { specialist }\end{array}$ \\
\hline Personality orientation & $\begin{array}{c}\text { Worldview, drives, desires, } \\
\text { aspirations, inclinations, ideals, } \\
\text { and beliefs }\end{array}$ & 17 & 14 \\
\hline Social experience & $\begin{array}{c}\text { knowledge, skills, abilities and } \\
\text { habits }\end{array}$ & 18 & 14 \\
\hline $\begin{array}{c}\text { Individual } \\
\text { psychological features }\end{array}$ & $\begin{array}{c}\text { Features of cognitive processes } \\
\text { (memory, thinking, will, } \\
\text { feelings, etc.) }\end{array}$ & 22 & 16 \\
\hline Biopsychic properties & $\begin{array}{c}\text { Speed, intensity of mental } \\
\text { processes, gender, age }\end{array}$ & 19 & 17 \\
\hline
\end{tabular}

At the 7th stage, the WG included the features of the NTI specialist model and the means of formation (diagnostics) determined by the experts in Table 4 - the draft model of the NTI specialist.

\section{Conclusions}

Thus, we obtained a draft model of the personality of an NTI specialist, built on the basis of the generalized opinion of experts. This model included a description of the features of an NTI specialist and a means of forming and diagnosing these qualities.

The process of forming the personality of an NTI specialist is inseparable from the system of education and upbringing. This process should be integrated and initiate the development of all personality structures. All participants in educational relations and representatives of specialists in the NTI industries should participate in this process. Methods for registering indicators of the formation of personality substructures of NTI specialists are pedagogical and psychological diagnostics and expert assessment. This presupposes positive dynamics in the development of the personality of NTI specialists.

\section{References}

1. Atlas of new professions, URL: http://atlas100.ru/

2. A.A. Miroshnichenko, D.R. Merzliakova, Bulletin of Udmurt University. Ser. philosophy, psychology, pedagogy, 29(3), 336 (2019)

3. N.A. Dmitriev, Bulletin of Tula State University. Humanitarian sciences, 2, 467 (2010)

4. E.Iu. Nadezhdina, E.A. Shaturnaia, Iu.I. Shtogrina, Eurasian Union of Scientists, 81(17), 128 (2015)

5. V.P. Bespalko, The components of pedagogical technology, 192 (2009)

6. A.A. Derkach, Acmeological foundations of professional development, 752 (2014)

7. A.A. Derkach, Acmeology: personal and professional development of a person. Methodological and applied foundations of axiological research, 391 (2010)

8. K.K. Platonov, Personality structure and development, 254 (2016)

9. R.A. Reznikova, K.S. Reznikov, Collection: Education and the City: practices of participatory design, Collection of articles on the results of the Second Annual International Symposium, 199 (2010) 
10. C. Brighton, Socio-cultural values in the development of intercultural communication competence, 217 (2013)

11. M.A. Khan, F.B. Ismail, A. Hussain, B. Alghazali, SAGE Open, 10, 1, first published January 23, 126 (2020) 